\title{
New metric products, movies, and 3D models from old stereopairs and their application to the in situ palaeontological site of Ambrona
}

\author{
José M. VALLE*, Álvaro RODRÍGUEZ, Rosa MARTÍNEZ, Pablo PÉREZ, Sandra UCEDA \\ \& Ane LOPETEGI
}

Laboratorio de Documentación Geométrica del Patrimonio - Grupo de Investigación en Patrimonio Construido (GPAC). Universidad del País Vasco/Euskal Herriko Unibertsitatea UPV/EHU. c/ Justo Vélez de Elorriaga, 1 (Centro de Investigación Micaela Portilla). 01006, Vitoria-Gasteiz, Spain; ldgp@ehu.eus

* Corresponding author

Valle, J.M., Rodríguez, Á., Martínez, R., Pérez, P., Uceda, S. \& Lopetegi, A. 2017. New metric products, movies, and 3D models from old stereopairs and their application to the in situ palaeontological site of Ambrona. [Nuevos productos métricos, vídeos y modelos 3D obtenidos a partir de pares estereoscópicos antiguos. Aplicación al yacimiento paleontológico in situ de Ambrona]. Spanish Journal of Palaeontology, 32 (2), 279-290.

\section{ABSTRACT}

3D modelling tools from photographic pictures have experienced significant improvements in the last years. One of the most outstanding changes is the spread of the photogrammetric systems based on algorithms referred to as Structure from Motion (SfM) in contrast with the traditional stereoscopic pairs. Nevertheless, the availability of important collections of stereoscopic registers collected during past decades invites us to explore the possibilities for re-using these photographs in order to generate new multimedia products, especially due to the fact that many of the documented elements have been largely altered or even disappeared. This article analyses an example of application to the re-use of a collection of photographs from the palaeontological site of Ambrona (Soria, Spain). More specifically, different pieces of software based on Structure from Motion (SfM) algorithms for the generation of 3D models with photographic textures are tested and some derived products such as orthoimages, video or applications of Augmented Reality (AR) are presented.

Keywords: Palaeontology, photogrammetry, Structure from Motion (SfM), 3D modelling, orthophotographs, Augmented Reality (AR).

\section{RESUMEN}

Las herramientas de modelado 3D a partir de imágenes fotográficas han experimentado avances muy significativos en los últimos años. Uno de los más destacados corresponde a la generalización de los sistemas fotogramétricos basados en los algoritmos denominados Structure from Motion (SfM) sobre los proyectos de documentación tradicional basados en pares estereoscópicos. La existencia de importantes colecciones de registros estereoscópicos realizados durante las décadas anteriores invita a explorar las posibilidades de reutilización de estos registros para la obtención de productos multimedia actuales, máxime cuando algunos de los elementos documentados han sufrido grandes modificaciones o incluso desaparecido. En el presente artículo se analiza la reutilización de colecciones fotográficas de yacimientos paleontológicos mediante un ejemplo centrado en el yacimiento de Ambrona (Soria, España). En concreto, se contrastan varios programas basados en los algoritmos denominados Structure from Motion (SfM) para la generación del modelo 3D con textura y otros productos derivados como ortoimágenes, vídeos o aplicaciones de Realidad Aumentada (RA).

Palabras clave: Paleontología, fotogrametría, Structure from Motion (SfM), modelado 3D, ortoimagen, Realidad Aumentada (RA). 


\section{INTRODUCTION}

The way in which the skeletal remains giving rise to a palaeontological site are distributed underground provides information essential for understanding the procedures of deposit, transport and subsequent transformations (see, for instance, Villa et al., 2005; Anzidei et al., 2012; Domínguez-Rodrigo et al., 2014; López et al., 2015). Furthermore, its geometric documentation allows us to show the sequence of excavation that exhumed and recovered the bones. Given that the extraction of the palaeontological elements implies the dismantling of the deposit, further studies and reinterpretations can only rely on the documentation (comprising, for instance, drawings, plans, photographs and video) done during the excavation.

One of the commonest ways to represent the layout of the remains as they were located during the excavation is a plan view in which the elements of interest are represented by line drawing (Alberdi et al., 1997; Tsoukala, 2000; Gaudzinski et al., 2005; Esperante et al., 2009; Albizuri et al., 2015; Ortega et al., 2015; Tschopp et al., 2015). The advantages of drawings include: 1) they are clear and easy to understand; 2) they are suitable for printing and publishing in reports and papers; 3 ) they provide great expressivity because the information that is displayed has been previously selected and is meaningful; 4) line drawings can be generated regardless of the available resources, either freehand or based on measures taken with tape, land surveying, photogrammetry, etc. Although the geometric precision and the level of detail differ in each case, the visual appearance of the product will be similar; and, 5) elements can be classified and enriched with additional information at the same time that they are outlined; therefore, this product is particularly well suited for GIS (Geographic Information System) implementation.

However, there also certain limitations, for instance, drawings leave little room for reinterpretation of base data and contexts since they only show the site as the author understood it, moreover, in some cases it can be difficult to represent the three-dimensionality of the elements and their arrangement.

Apart from line drawing, nowadays it is possible to generate very detailed photomosaics (Fisher et al, 2015), as well as 3D models, with a precision of a few millimetres and with photographic texture by means of laser scanners (McPherron et al., 2008), or photographic collections (Mallinson \& Wings, 2014). Thanks to the 3D models, we can recreate the site with a great deal of realism, which not only facilitates the study but also offers new possibilities of dissemination.

Both products, line drawings and 3D models, are clearly complementary. Taking this into account, the present article analyses the possibilities of generating 3D models from archival collections of photographs of palaeontological sites of which only line drawings are available (or no drawing exists at all). The aims of this research are, firstly, to enrich two-dimensional representations (for instance, by adding an orthoimage or a set of cross-sections) and, secondly, to review a set of new 3D products as used either on computers or on mobile devices through applications of Augmented Reality (AR). These points are made by means of a case study based on the data generated in 2008 during the geometric documentation of the in situ museum of Ambrona (Soria, Spain). With the results of such a study, final users will have at their disposal new ways to approach, study and enjoy palaeontological heritage.

At first sight, it may seem surprising that we consider less than ten-year-old information as archive information, however, it is appropriate to clarify that the term "archival" is age-independent. Indeed, the Multilingual Archival Terminology of the International Council of Archives (ICA) clearly stated that the key aspect of a record is its purpose of giving evidence of a fact and not the number of years since the piece of information was created. In our case, information (e.g. a photograph) acquires the character of archival at the time that the appearance of the site changes (for example, due to excavation, in situ musealization, etc.) and, therefore, stands as a testimony of how it was. Moreover, in the digital era, the continuous development of new technologies to process data makes easier to generate formerly considered unattainable products, hence the interest in keeping available the information about previous interventions on the palaeontological sites.

\section{MATERIALS AND METHODS}

Excavation is a destructive process. Only exceptionally, as in the in situ museum in Ambrona, it is possible to see the site as it got exposed through the excavation. Indeed, this place consists of a room of about 8 by 8 metres in plan, corresponding to a protective cover built up in 1963 around a group of bone remains. Such remains mainly belong to four or five specimens of elephant Elephas (Palaeoloxodon) antiquus (Falconer \& Cauteley, 1847) that lie together with some other sparse bones of horse, deer and bovid, as well as some pieces of lithic industry.

Over the years, the elements exposed in Ambrona had undergone a remarkable degradation that had affected both the bones and the terrain on which they lie. The problems presented by these elements include the darkening of the protective coating that was applied on the bones (polyester and acrylic resin), as well as its disaggregation, exfoliation and fragmentation. Moreover, desiccation of the clays of the substratum was evident through cracking and widespread detachments. Given this situation, the Department of Culture and Tourism of the Junta de Castilla y León (regional administration responsible 
for the museum) called for tenders for the works of restoration of the complex in 2008. The solicitation document specified that one of the products that the bidder had to generate was a line drawing similar to those mentioned above. In particular, a plan was required that was obtained by stereoscopic photogrammetry and included the bones, identified according to the codification established in the museum catalogue and the indication of heights (Figs. 1-2).

Photographs were taken with a camera Canon EOS 5D (12 megapixels) and a $35 \mathrm{~mm}$ fixed lens, a temporary and portable suspended structure was set up on site in order to take vertical pictures from a suitable distance ( 2 metres from the ground, which generate images covering an area of around 2 metres by 1.4 metres) at the same time that the displacement of the camera, and therefore the overlap between images, could be accurately controlled. These overlaps were $60 \%$ along the strips and $40 \%$ between consecutive strips. The resulting line drawing was prepared to be printed at scale 1:20.

The recent development of innovative techniques of photogrammetric processing and, above all, the algorithms
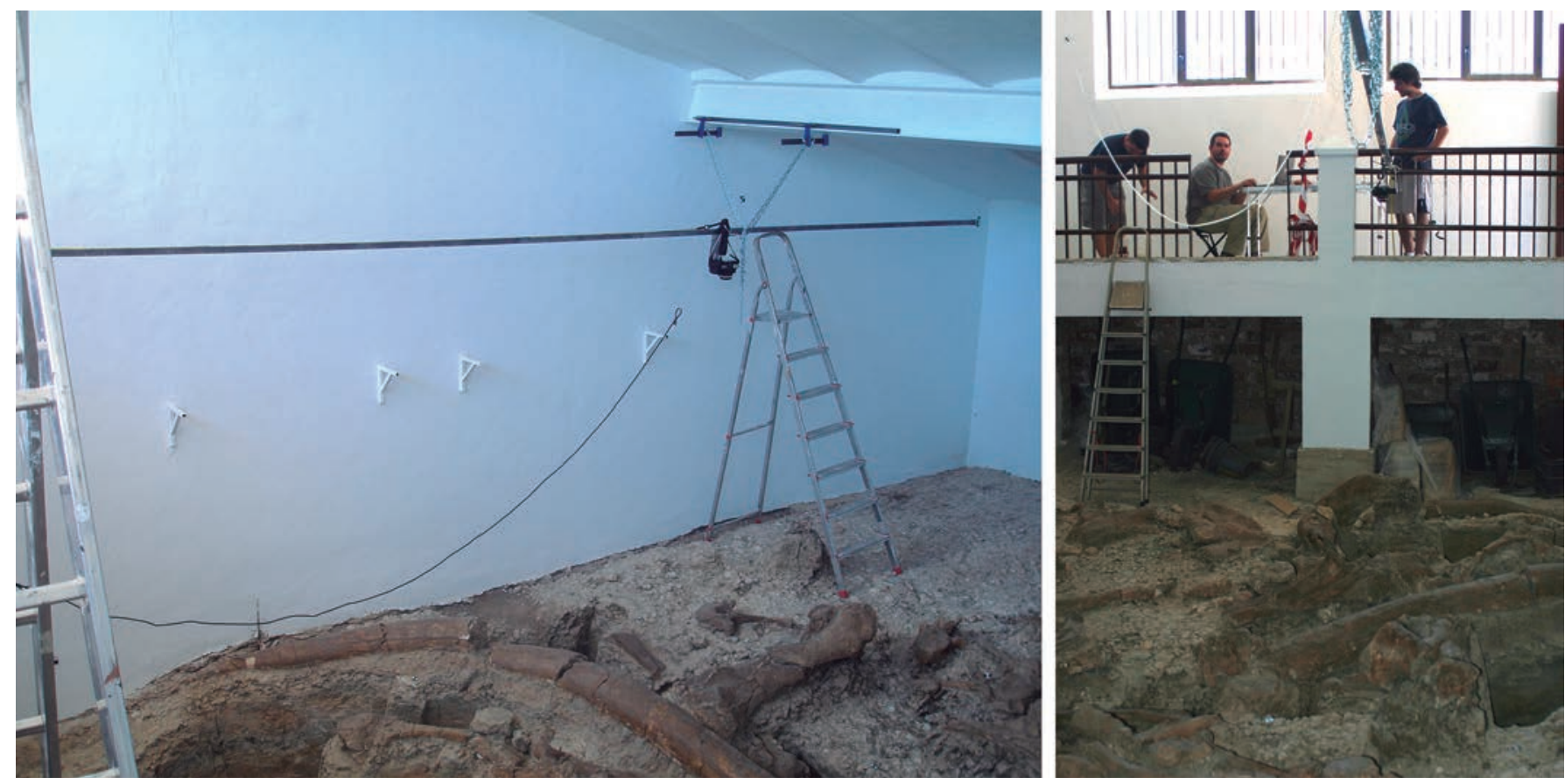

Figure 1. Two views of the structure mounted for carrying the camera upright during the shooting of the stereopairs (LDGP, 2008). All in all, 195 photographs arranged in 13 strips were taken.

called Structure from Motion (SfM) allow us to generate 3D models from groups of pictures quite freely in terms of geometric constraints, characteristics of the cameras, lighting conditions, etc. (Pereira, 2013; Benavides et al., 2016). In addition, the available software packages (123D Catch, PhotoScan, PhotoSynth, MicMac, Scann3D, VisualSFM, Pix4D, etc.) run mostly automatically, which greatly simplifies the workflow. Furthermore, several of them have affordable prices (or are simply free software). Some of them provide cloud computing (Hwang et al., 2012), hence, although the procedure is computationally demanding, good results are attainable even for producers with basic hardware. Finally, websites for the storage, sharing and dissemination of 3D contents (such as SketchFab) provide simple ways to visualize interactively the virtual models and help to get feedback from final users.
In this context, it seems appropriate to review the applicability of this kind of tools to archive photographs such as the collection described in the case of Ambrona. Indeed, the value of historical photographs for the generation of new 3D contents has often been identified but, at the same time, it has been noted that they are not always suitable for automatic processing with the available techniques. Therefore, this is still an open topic that needs further research (de Polo \& Calic, 2014). Sometimes, the rather paradoxical situation holds that better results are obtained in 3D reconstruction by using groups of lowquality casual pictures than by resorting to stereoscopic collection of photographs captured by following the strictest requirements of the classical photogrammetric procedure (Rodríguez Miranda et al., 2015). 


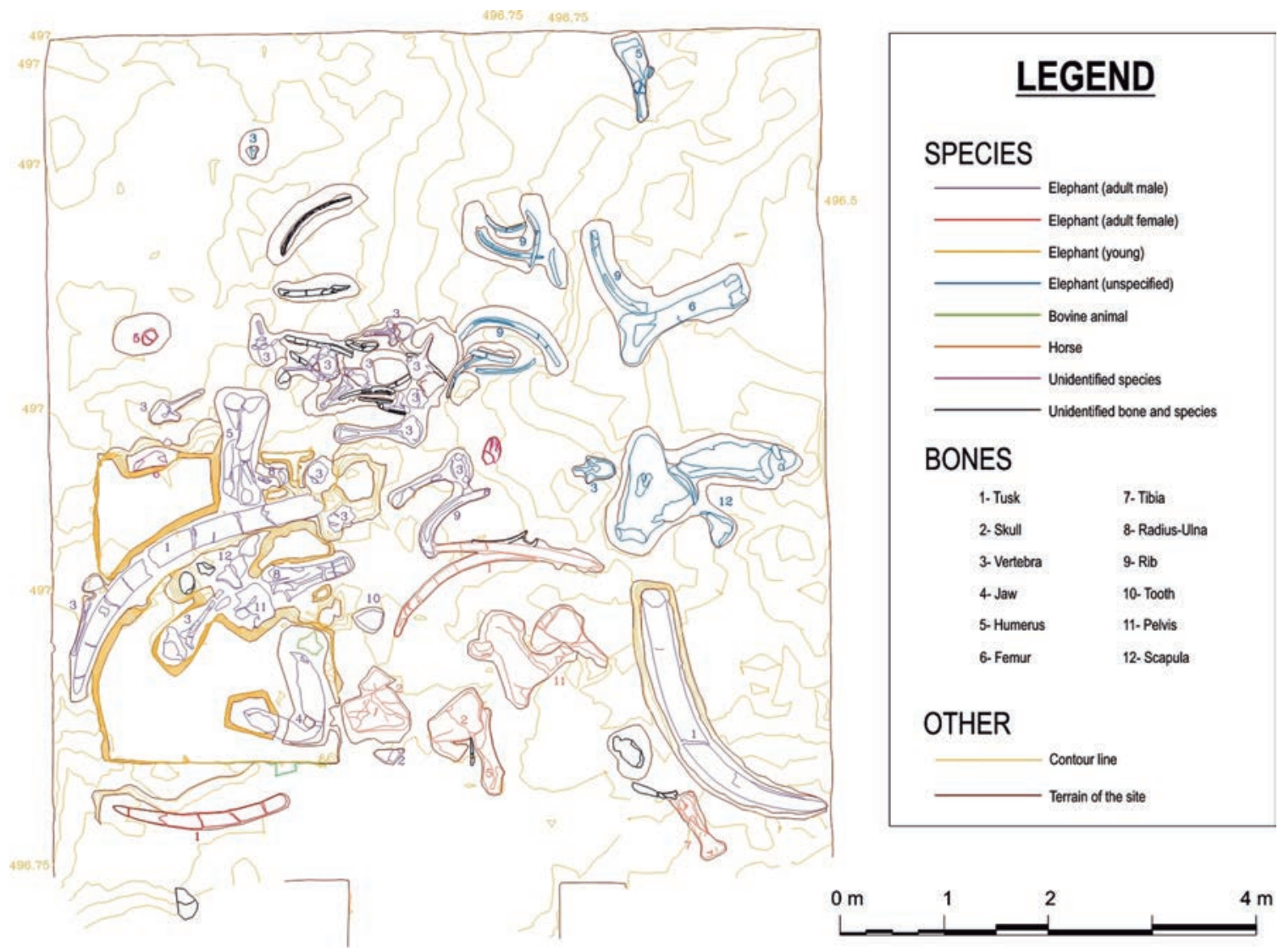

Figure 2. Top view plan with the line drawing of the bones and the indication of pathologies (cracks, fragmentation, etc.), coded according to the established criteria. Heights are indicated by means of contour lines.

\section{SYSTEMATIC PALAEONTOLOGY}

As indicated above, the most representative species in the exhibition space is the elephant Elephas (Palaeoloxodon) antiquus, (Falconer \& Cauteley, 1847). Nevertheless, it has to be borne in mind that the museum in situ contains only $64 \mathrm{~m}^{2}$ of the more of 6000 of the whole deposit (Santonja, 2005). For further information on the fauna found all over the site, readers are referred to comprehensive reports (Sesé \& Soto, 2005).

\section{RESULTS}

The set of 195 pictures taken in 2008 were processed with the following software: VisualSFM (free software, locally installed) (http://ccwu.me/vsfm/), 123D Catch (free software, it works remotely via web within company's servers) (http://www.123dapp.com/catch), and PhotoScan (commercial software, locally installed) (http://www. agisoft.com/).

In all three cases, the first stages of the information processing are automatic: once the image files have been selected, the software performs the detection and matching of common features in the photographs. Then, the orientations of the photographs are computed, that is to say, the coordinates of the origin of each view and the direction to which they are pointing in a three-dimensional space. Finally, a point cloud of the photographed surface is obtained by means of the intersection of the optical rays issuing from the points of view and passing through a common feature detected in more than one picture.

All programmes succeeded in orientating the photographs. The results of the three-dimensional reconstruction of the site are summarized below:

1) The software $123 \mathrm{D}$ Catch is limited to 70 pictures for model and, consequently, the set of photographs needed to be divided into three blocks. As can be seen in Figure 3, since all the points of view are from the top, the resulting models have several empty areas located on vertical surfaces and nooks under the bones. Gaps in threedimensional models are rather common when working with archive information. Unlike new projects, in which the data capture can be planned so as to encompass all the areas of interest with enough overlap and a suitable geometry of the photographs in order to be able to compute the point cloud accurately, the coverage provided by archival collections 


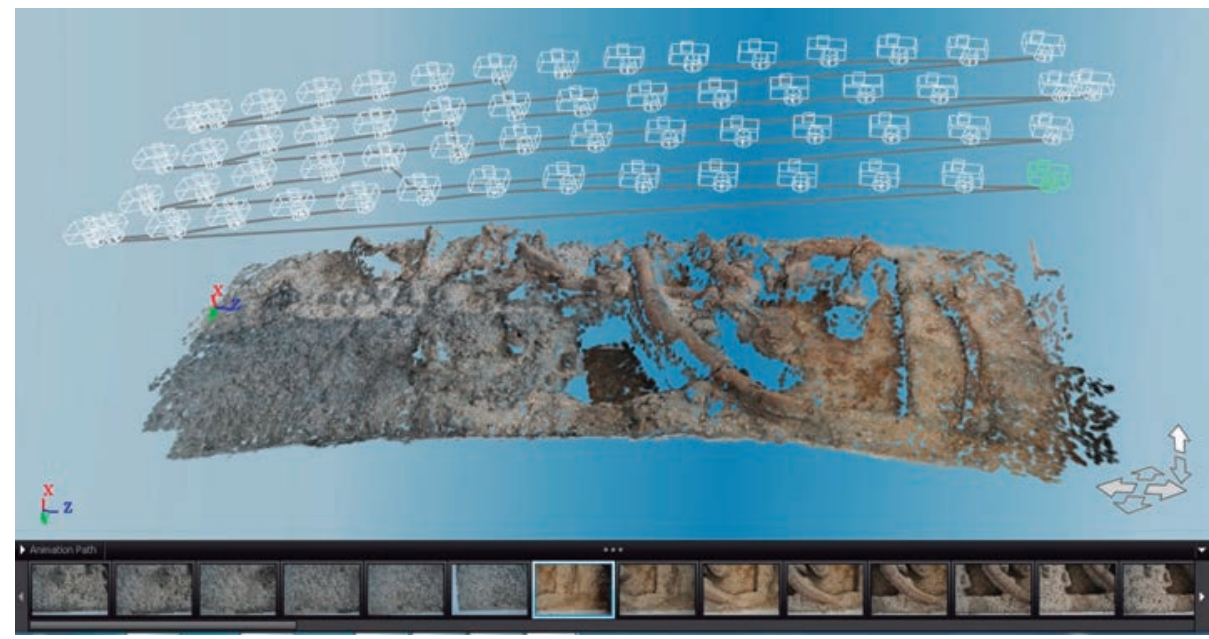

Figure 3. Screenshot of the software 123D Catch, in which a threedimensional view of the terrain model is presented in form of point cloud. The location of the cameras is also shown. The model corresponds to four strips (59 pictures).

tends to be variable. Besides, do take into account that the archival collection shows a past state of the site, different from the one today, therefore it is no longer possible to return to the place and take additional photographs in order to complete the missing information.

2) On the other hand, the software VisualSFM was able to compute the whole set of pictures at the same time. However, like the abovementioned case, the outcome shows gaps on surfaces that can be seen in the photographs under slant angles and hidden areas under the bones (Fig. 4). It must be taken into account that, in order to accurately determine the $3 \mathrm{D}$ coordinates of a point on the surface, this software requires the presence of a given point in at least three photographs.
3) Finally, the complete site was also modelled together with the software PhotoScan. The resulting point cloud was similar to the ones described above (Fig. 5).

From this phase on, the processing varies according to the functionalities of each software package. For instance, PhotoScan permits the generation of a polygon mesh surface based on the point cloud of the terrain. In the following step, this mesh can be wrapped with the photographic texture so as to provide a very realistic outcome (Fig. 6). Polygon mesh generation fills the gaps between points, with which the result is a continuous model of the site. Nevertheless, it should not be forgotten that the interpolated areas correspond to an assumed geometry that needs to be checked (at least, visually) and
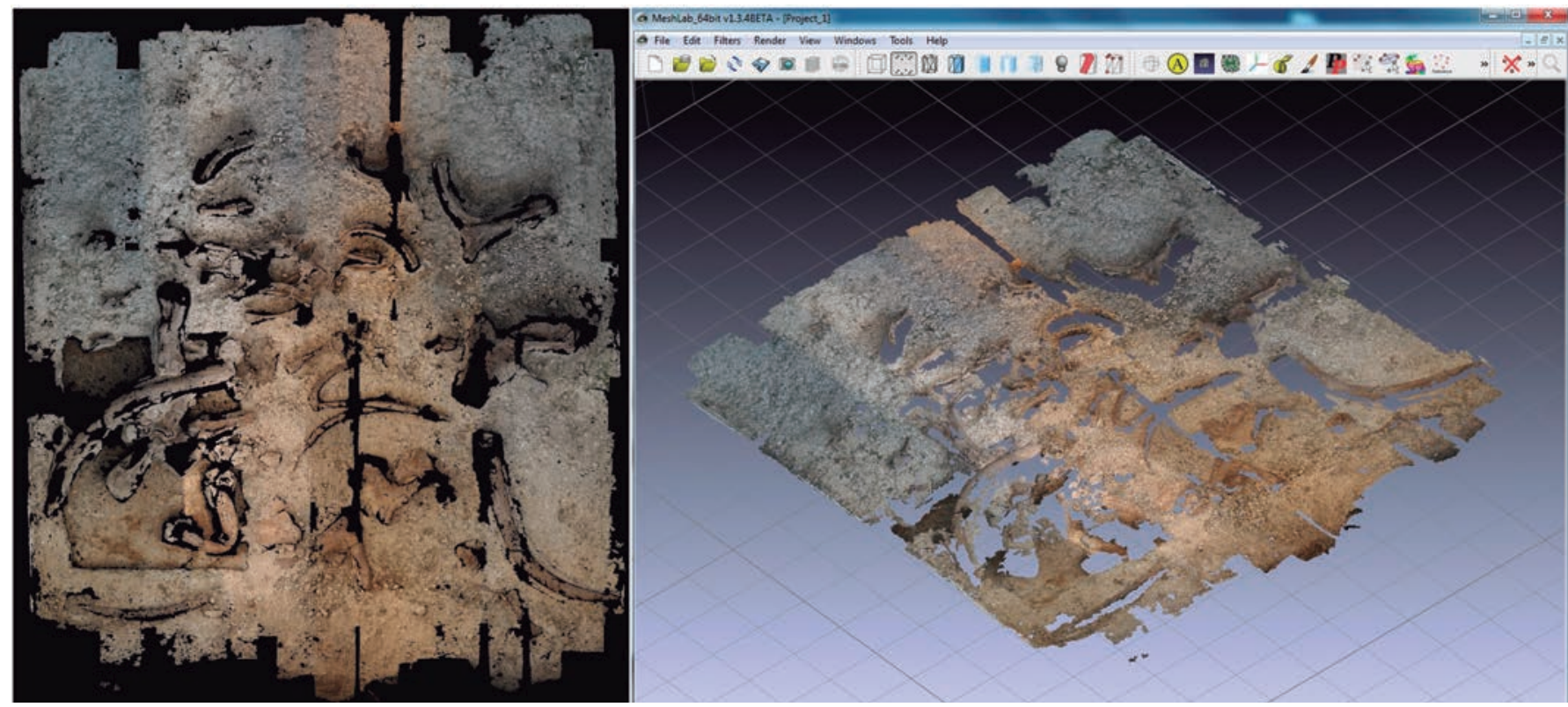

Figure 4. Top view (on the right) and perspective view (on the left) of the point cloud generated with the software VisualSFM, in which the parts reconstructed correctly and the empty areas are clearly shown. 


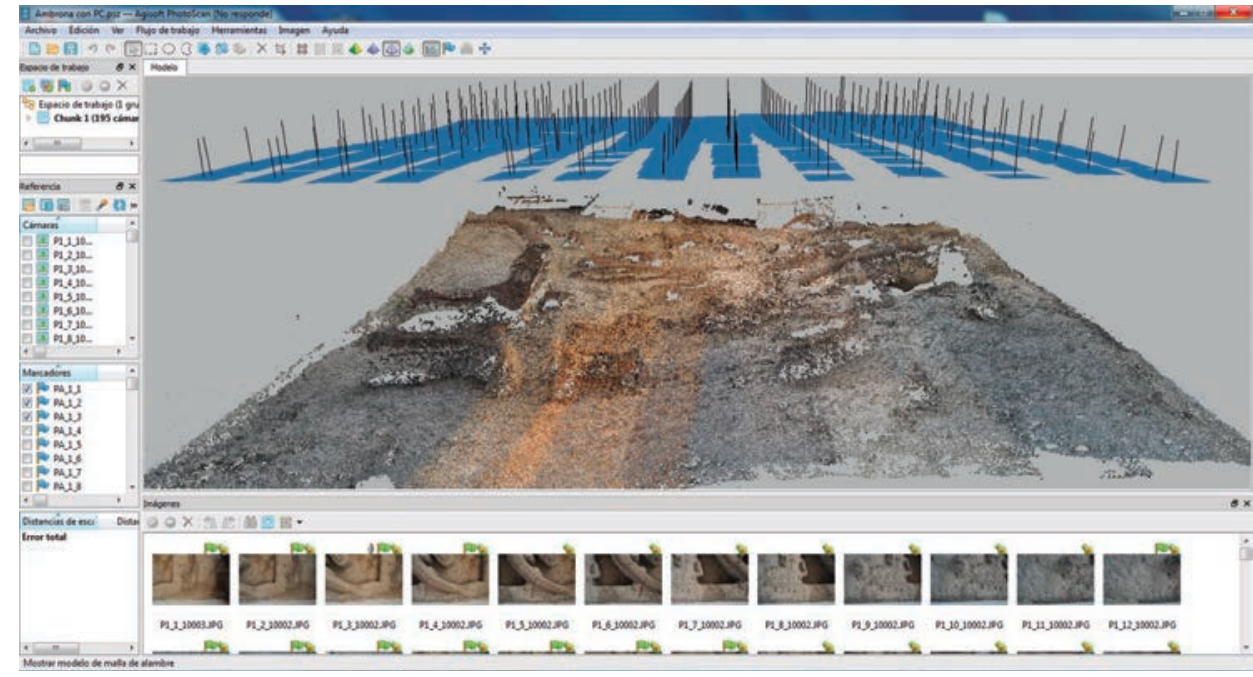

Figure 5. Screenshot of the software PhotoScan. As in Figure 3, the perspective view shows together the point cloud representing the surface of the site and the location of the cameras (blue quadrilaterals). that the quality of such interpolated areas, both in geometry (form) and as far as radiometry (texture) is concerned, is poorer than where points actually exist.

Regarding the radiometry of the images, the software tries to adjust the colour of the pictures in order to homogenize tone, lightness and saturation. In the case of Ambrona, the use of the metallic structure that was mounted for carrying the camera strictly upright to the ground increased the time necessary for taking the photographs up to two complete workdays, which resulted in a great variation of the lighting conditions between pictures. As a consequence, in spite of the radiometric correction, some banding effects still remain in the textured model.

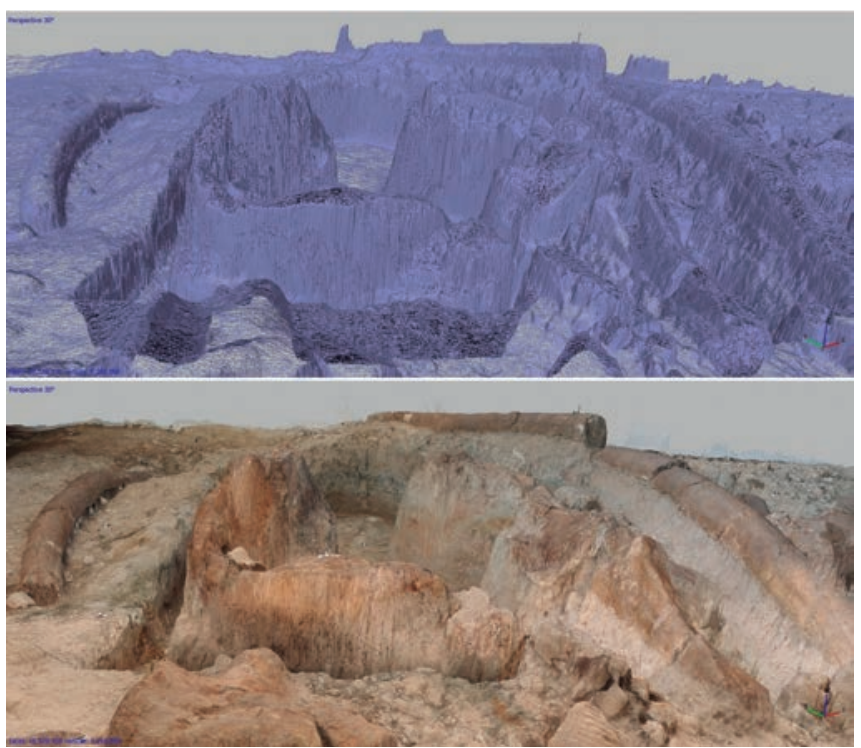

Figure 6. Polygon mesh model. On top, only the geometry of the mesh is shown while, at the bottom, the geometry is mapped with the photographic texture. The surface of the site is comprised of around three millions of polygons, that is to say, 1 vertex every $3 \mathrm{~mm}$ on the ground.
To obtain the same product (polygon mesh model with photographic textures) from the data generated with the other two computer programmes reviewed above, specialized software for three-dimensional modelling, such as MeshLab (http://meshlab.sourceforge.net/) is required. Indeed, VisualSFM does not generate the mesh. As for 123D Catch, although this software does compute the mesh and map the textures, in the case of Ambrona, the site would have to be split in three partial models due to the large amount of photographs. Therefore, before generating the polygon mesh, it would be necessary to merge them and no tools are provided along with this software to carry out this task.

Either way, once the polygon mesh has been generated and the texture mapped, the 3D model needs to be scaled and levelled. For this purpose, just before the photogrammetric documentation of 2008 a group of 120 control points were set all over the surface of the site (Fig. 7). These points consisted of $3 \times 3 \mathrm{~cm}$ targets made of methacrylate, the three-dimensional coordinates of which were obtained by means of a total station with an accuracy of around $3 \mathrm{~mm}$. By identifying at least three of these points in the virtual model of the site, the coordinate transformation can be calculated that refers the virtual model to the coordinate system defined by the control points, with more of three points, the redundancy provides information about the geometric quality of the virtual model.

With this aim, the coordinates of the complete set of control points were measured in the virtual model and compared with the values obtained with the total station. In the model of Ambrona, all the points differed less than $2 \mathrm{~cm}$, the average error being $8 \mathrm{~mm}$. Given the dense array of control points used in the evaluation test, these error values can be considered representative of any part of the 3D model. 


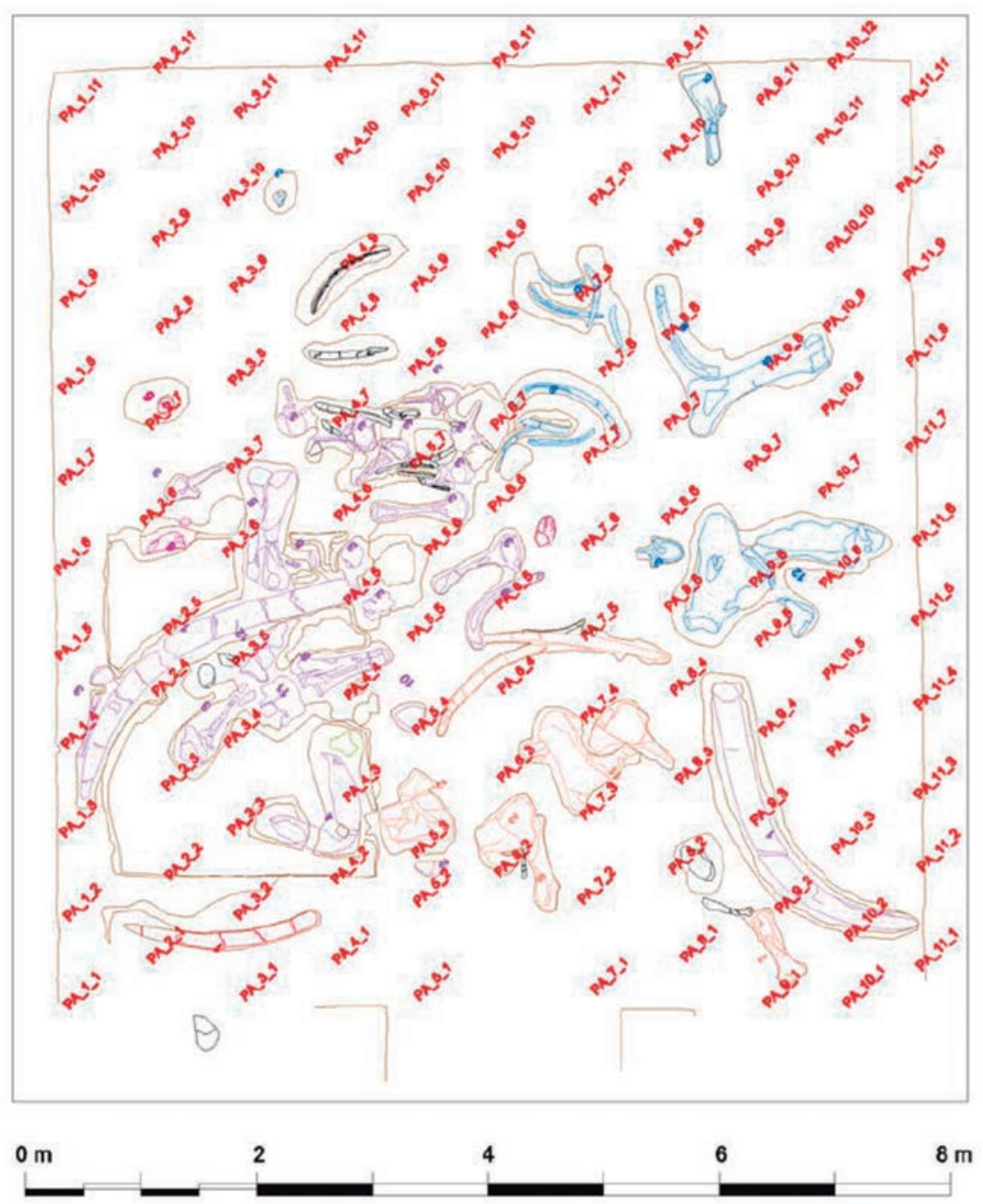

Figure 7. Layout of the control points in the original project of stereoscopic photogrammetry (year 2008). The arrangement is approximately regular with a spacing of around $80 \mathrm{~cm}$ between points. This density is due to the condition that at least four points are visible in every picture. The orientation of the block was done by triangulation (bundle adjustment), the computed precision of the control points after the adjustment is better than $1 \mathrm{~cm}$.

Then, the generated 3D model can be exported to different file formats (such as .obj, .ply, .pdf-3D, etc.), so that it can be used in multiple programmes, thus allowing its interactive exploration and the generation of derived products like cross-sections, orthometric views, etc. (Fig. 8).

Among all the possible views of the virtual model, the orthographic view from the top was particularly important because it could be integrated into the line drawing generated in 2008. In this way, the information provided by the plan was enriched by the photographic texture and shows more clearly the state of conservation of the bones and the terrain (Fig. 9).

Other choices for integrating 3D models are the videos and the applications of Augmented Reality (Ruiz, 2013). In Augmented Reality, the virtual model is superimposed on the real image that the user is watching through the camera of a mobile device such as a phone or a tablet. It requires a marker (something in the real world) that the application can recognise and use as the reference where the $3 \mathrm{D}$ model will be placed. The 3D model can be explored interactively by moving the camera or the marker, which creates an immersive experience that is useful and relevant not only in scientific contexts but also for dissemination in museums as well as for touristic purposes (Esclapés et al., 2013) (Fig. 10).

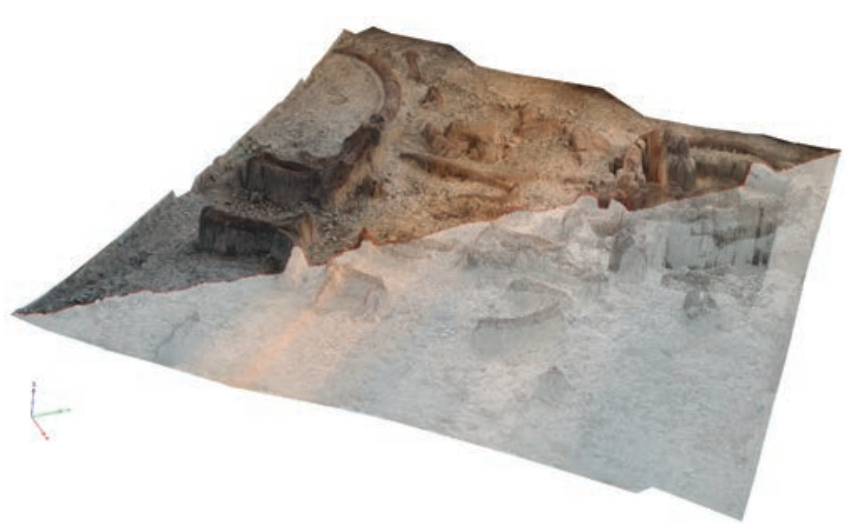

Figure 8. Perspective view of the 3D model, over which a crosssection has been marked in red along the diagonal of the site, the part of the model in front of the red line is represented with semitransparent meshes in order to show the cross-section more clearly. 


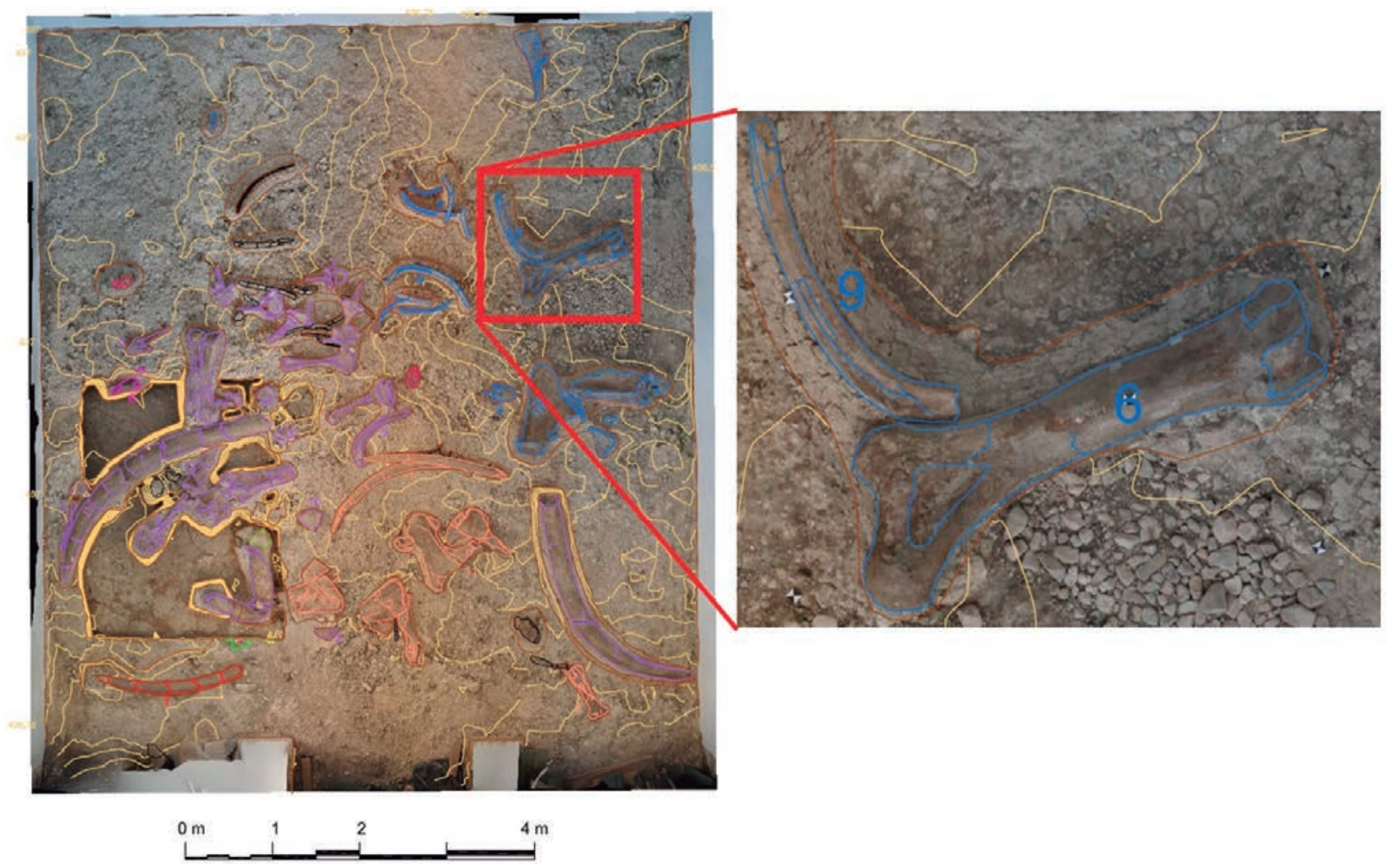

Figure 9. Top view orthoimage integrated as the background of the line drawing. Complete site (left) and detail (right).

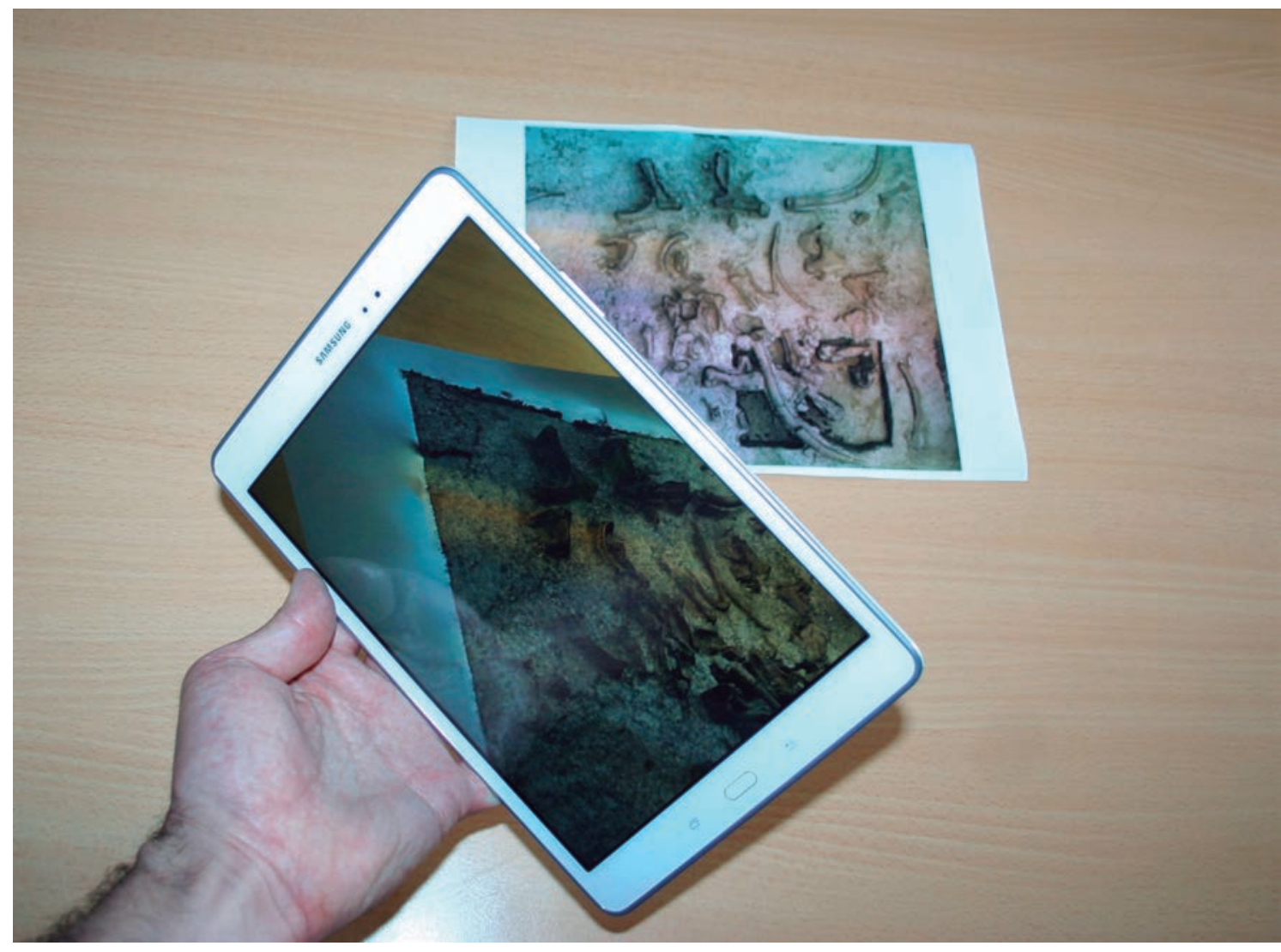

Figure 10. Interactive view of the 3D model in a tablet. The piece of paper with the orthoimage of the site acts as the marker on which the $3 \mathrm{D}$ model is placed. 
In our case, the application was created with the plugin Vuforia (https://www.vuforia.com/) in the 3D modelling environment Unity 3D (http://unity3d.com/). We used as a marker the orthographic plan view, thus making it easier to establish the link between the cartographic document and the real appearance of the site (Valle Melón et al., 2016). The procedure started by inserting the plan view in form of an image file (e.g., a .jpg file). Then, the 3D model of the palaeontological site (previously exported from the photogrammetric software in a exchange format such as .obj) was also added to the scene and placed just above the target. This step required the adjustment of the scale and the orientation of the model, so that when the 3D models pops up on the screen of the mobile device its position and size fits exactly with the image on the target. Next, a camera and a lighting source were set in order to complete the scene. Finally, the application was exported for the selected kinds devices (namely .apk package for Android).

\section{DISCUSSION}

Leaving aside the computer tools used, we shall try to make some generalisations concerning the recovery of photographic information with the aim of generating new metric and dissemination products of palaeontological sites.

The first aspect to be mentioned is the availability of baseline information (archive photographs), in the absence of which it would be impossible to generate any new product. In order to guarantee this, suitable courses of action are required both during the generation of the collections and along their maintenance (Rodríguez Miranda \& Valle Melón, 2010). Examples of the actions to be considered include the definition of quality criteria of data capture so as to ensure that pictures are rich and detailed enough for the desired purposes, the establishment of means for the preservation of datasets over time, their classification, the definition of how future users will access the information, etc.

Secondly, the current trend in computer software for 3D modelling favours low cost programmes with a great level of automation. This situation benefits the reuse of information, not only for the sake of price cut but also because the reduction of the time and hardware requirements necessary for the management of data expands the range of potential producers that can generate this kind of results.

Nevertheless, in scientific contexts, it would not be adequate to accept, without proper discussion and assessment, products that are generated automatically. On the contrary, it is necessary to evaluate them in order to determine their quality (missing areas, geometric precision, quality of the textures, etc.).

Another interesting point is the evolution of the software. This issue is particularly important for the online services, since users can only run the service as it is being provided at each given moment. For instance, 123D Catch was discontinued by the owner (Autodesk) at the beginning of 2017 and replaced by a new suite under the designation Autodesk Remake (https://remake.autodesk. com/about), meanwhile, other similar services, like Microsoft Photosynth, were just shut down suddenly with little explanation. There are also pieces of software still available but without maintenance, such as VisualSFM. In contrast, new computer programs are constantly being put on the market. In short, current development in terms of software is very dynamic. Anyway and despite the specific software available at any time, the three examples presented here can be considered representative of the different options that nowadays can be found. In particular, commercial versus free software, locally installed against cloud computing and complete suites (orientation, point cloud computing, meshing, etc.) in contrast with individual components that the user need to combine.

Finally, it must be borne in mind that the habits and the needs of the users are constantly evolving. Therefore, the need of re-using old information once and again in order to meet the users' new expectations will be a permanent challenge. A clear example is the application of Augmented Reality through mobile devices, a product that was hardly known just a few years ago but that has become a booming demand nowadays.

\section{CONCLUSIONS}

In this paper, the photographic information registered during the restoration works done in 2008 at the palaeontological site of Ambrona has been re-used so as to evaluate the current possibilities of re-processing it and generating new metric and dissemination products. In particular, 3D models with photographic textures, orthoimages and applications of Augmented Reality have been considered.

The new products help to increase the knowledge of the state of the site in 2008 (before its consolidation). Although the products are constrained by the base data (such as the hidden parts in the photographs), the case study shows a significant improvement in relation to the original line drawing both in terms of the two-dimensional representation (after having added the orthoimage) and thanks to the interaction with the three-dimensional virtual model.

In the same line, these products provide a closer interaction with users and open new venues of dissemination 
and study of the elements of the site. Bearing in mind that generation costs are rather affordable, we consider that there is a huge potential for this kind of work, provided that interested producers and users have easy access to the base information (that is to say, to the archive photographs and additional data). All this highlights, once again, the importance of the correct documentation and preservation of data in palaeontological studies.

\section{ACKNOWLEDGEMENTS}

The project for the consolidation of the palaeontological site was commissioned in 2008 by the Junta de Castilla y Leon to the company Insitu Restauración, which in turn counted on our laboratory for the geometric documentation of the state of the site before the works. We are grateful for their confidence. On the other hand, the authors would like to thank the reviewers for their constructive pieces of advice and corrections and the editor of the journal for their constant encouragement during the review process.

\section{REFERENCES}

Alberdi, M.T., Cedeño, E., López-Martínez, N., Morales, J. \& Soria, M.D. 1997. La fauna villafranquiense de El Rincón-1 (Albacete, Castilla-La Mancha). Estudios Geológicos, 53, 69-93.

Albizuri, S., Maroto, J., Nadal, J., Majó, T., Sánchez Marco, A., Carlus, X., Rodríguez, A. \& Palomo, A. 2015. Wild carnivore and wild bird deposits ina an agro-pastoral community during the Bronze Age: Can Roqueta II (northeast Iberian Peninsula). Munibe AntropologíaArkeologia, 66, 163-184.

Anzidei, A.P., Bulgarelli, G.M., Catalano, P., Cerilli, E., Gallotti, R., Lemorini, C., Milli, S., Palombo, M.R., Pantano, W. \& Santucci, E. 2012. Ongoing research at the late Middle Pleistocene site of La Polledrara di Cecanibbio (central Italy), with emphasis on humanelephant relationships. Quaternary International, 255, 171-187; doi: 10.1016/j.quaint.2011.06.005.

Benavides, J.A., Aranda Jiménez, G., Sánchez Romero, M., Alarcón García, E., Fernández Martín, S., Lozano Medina, A. \& Esquivel Guerrero, J.A. 2016. 3D modeling in archaeology: The application of Structure from Motion methods to the study of the megalithic necropolis of Panoria (Granada, Spain). Journal of Archaeological Science: Reports, 10, 495-506; doi: 10.1016/j.jasrep.2016.11.022.

de Polo, A. \& Calic, J. 2014. The role of photography in 3D multimedia systems. In: Digital Heritage. Progress in Cultural Heritage: Documentation, Preservation and Protection (eds. Ioanides, M., Magnenat-Thalmann, N., Fink, E., Žarnić, R., Yen, A.-Y. \& Quak, E.). $5^{\text {th }}$ International Conference, EuroMed 2014. pp. 366-375.
Domínguez-Rodrigo, M., Bunn, H.T., Mabulla, A.Z.P., Baquedano, E., Uribelarrea, D., Pérez-González, A., Gidna, A., Yravedra, J., Diez-Martin, F., Egeland, C.P., Barba, R., Arriaza, M.C., Organista, E. \& Ansón, M. 2014. On meat eating and human evolution: A taphonomic analysis of BK4b (Upper Bed II, Olduvai Gorge, Tanzania), and its bearing on hominin megafaunal consuption. Quaternary International, 322-323, 129-152; doi: 10.1016/j.quaint.2013.08.015.

Escaplés, J., Tejerina, D., Bolufer, J. \& Esquembre, M.A. 2013. Sistema de Realidad Aumentada para la musealización de yacimientos arqueológicos. Virtual Archaeology Review, 4, 42-47; doi: 10.4995/var.2013.4246.

Esperante, R., Muñiz Guinea, F. \& Nick, K.E. 2009. Taphonomy of a Mysticeti whale in the Lower Pliocene Huelva Sands Formation (Southuern Spain). Geologica Acta, 7, 489-505; doi: 10.1344/105.000001451.

Falconer, H. \& Cautley, P.T. 1847. Fauna Antiqua Sivalensis. Atlas, Smith, Elder and Co., London. pp. 1-90.

Fisher, E.C., Akkaynak, D., Harris, J., Herries, A.I.R., Jacobs, Z., Karkanas, P., Marean, C.W. \& McGrath, J.R. 2015. Technical considerations and methodology for creating high-resolution, color-corrected, and georectified photomosaics of stratigraphics sections at archaeological sites. Journal of Archaeological Science, 57, 380-394; doi: 10.1016/j.jas.2015.02.022.

Gaudzinski, S., Turner, E., Anzidei, A.P., Álvares-Fernández, E., Arroyo-Cabrales, J., Cinq-Mars, J., Dobosi, V.T., Hannus, A., Johnson, E., Münzel, S.C., Scheer, A. \& Villa, P. 2005. The use of proboscidean remains in every-day palaeolithic life. Quaternary International, 126-128, 179194; doi: 10.1016/j.quaint.2004.04.022.

Hwang, J.-T., Weng, J.-S. \& Tsai, Y.-T. 2012. 3D Modeling and accuracy assessment- A case study of Photosynth. $20^{\text {th }}$ International Conference on Geoinformatics. IEEE. Hong Kong (China); doi: 10.1109/Geoinformatics.2012.6270356.

LDGP (Laboratorio de Documentación Geométrica del Patrimonio). 2008. Levantamiento Fotogramétrico del Yacimiento Paleontológico "Museo in situ" de Ambrona (Soria). Laboratorio de Documentación Geométrica del Patrimonio (UPV/EHU).

López, P., Cartajena, I., Carabias, D., Morales, C., Letelier, D. \& Flores, V. 2016. Terrestrial and maritime taphonomy: differential effects on spatial distribution of a Late Pleistocene continental drowned faunal bone assemblage from the Pacific coast of Chile. Archaeological and Anthropological Sciences, 8, 277-290; doi: 10.1007/ s12520-015-0275-y.

Mallison, H. \& Wings, O. 2014. Photogrammetry in paleontology - A practical guide. Journal of Paleontological Techniques, 12, 1-31.

McPherron, S., Gernat, T. \& Hublin J.-J. 2008. Structured light scanning for high-resolution documentation of in situ archaeological finds. Journal of Archaeological Science, 36, 19-24; doi: 10.1016/j.jas.2008.06.028.

Ortega, F., Bardet, N., Barroso-Barcenilla, F., Callapez, P.M., Cambra-Moo, O., Daviero-Gómez, V., Díez Díaz, V., Domingo, L., Elvira, A., Escaso, F., García-Oliva, M., 
Gómez, B., Houssaye, A., Knoll, F., Marcos-Fernández, F., Martín, M., Mocho, P., Narváez, I., Pérez-García, A., Peyrot, D., Segura, M., Serrano, H., Torices, A., Vidal, D. \& Sanz, J.L. 2015. The biota of the Upper Cretaceous site of Lo Hueco (Cuenca, Spain). Journal of Iberian Geology, 41, 83-99; doi: 10.5209/rev_JIGE.2015.v41.n1.48657.

Pereira, J.M. 2013. Modelado 3D en patrimonio cultural por técnicas de structure from motion. PH Investigación, 1, 77-87.

Rodríguez Miranda, Á. \& Valle Melón, J.M. 2010. Claves metodológicas para la adquisición y uso de colecciones fotográficas de elementos patrimoniales. Cuadernos de Prehistoria y Arqueología de la Universidad de Granada, 20, 11-23.

Rodríguez Miranda, Á., Pérez Vidiella, P., Martínez Lázaro, R. \& Valle Melón, J.M. 2015. Reutilización de pares fotogramétricos de elementos arquitectónicos para la obtención de modelos 3D y ortofotografías a partir de técnicas SFM. Arqueología de la Arquitectura, 12, e024, doi: 10.3989/arq.arqt.2015.004.

Santonja, M. 2005. Esperando el Diluvio. Ambrona y Torralba hace 400.000 Años. Museo Arqueológico Regional de Madrid and Junta de Castilla y León. Madrid (Spain).
Sesé, C. \& Soto, E. 2005. Los yacimientos paleolíticos de Ambrona y Torralba (Soria). Un siglo de investigaciones arqueológicas. Zona Arqueológica, 5, 258-280.

Tschopp, E., Wings, O., Frauenfelder, T. \& Brinkmann, W. 2015. Articulated bone sets of manus and pedes of Camarasaurus (Sauropoda, Dinosauria). Palaeontologia Electronica, 18.2.44A, 1-65.

Tsoukala, E. 2000. Remains of a Pliocene Mammut borsoni (Hays, 1834) (Proboscidea, Mammalia), from Milia (Grevena, W. Macedonia, Greece). Annales de Paléontologie, 86, 165-191.

Valle Melón, J.M., Pérez Vidiella, P., Rodríguez Miranda, Á., D’Anna, C.M., Uceda Queirós, S., Sánchez Velasco, J. \& Akizu Gardoki, O. 2016. El modelo 3D como base para la documentación y diffusion de los elementos patrimoniales. Aplicación al mausoleo romano denominado 'la Sinagoga' de Sádaba (Zaragoza, España). Restauro Archeologico (RA), 25, 4-19; doi: 10.13128/RA-19316.

Villa, P., Soto, E., Santonja, M., Pérez-González, A., Mora, R., Parcerisas, J. \& Sesé, C. 2005. New data from Ambrona: closing the hunting versus scavenging debate. Quaterary International, 126-128, 223-250; doi: 10.1016/j.quaint.2004.03.001. 
